\title{
Pengaruh Komponen Keputusan Keuangan Terhadap Nilai Perusahaan
}

\section{Bernarda Kriswulan Bucharni \& Swarmilah Hariani}

Fakultas Ekonomi dan Bisnis, Universitas Mercubuana Jakarta, Indonesia

\section{Research Paper}

Financial Management

\begin{abstract}
This research was conducted to analyze the impact of investment decisions, funding decisions, and dividend decisions on firm value. The object of this research is the sector of trading and service companies listed on the Indonesia Stock Exchange. The sampling method in this research used the purposive sampling technique to get as many as 70 samples. The data analysis process used multiple linear regression analysis models processed by SPSS 25 application software. The results of this research indicate that investment decisions and dividend decisions have a significant positive effect on firm value. Meanwhile, funding decisions do not affect firm value.
\end{abstract}

\section{Keywords:}

Firm value; investment decisions; funding decisions; dividend policy

\section{Corresponding Author:}

Bernarda Kriswulan Bucharni

Universitas Mercu Buana

katarinabernarda.32@gmail.com

DOI: https://doi.org/10.36407/akurasi.v3i3.537
Received: 18 Oct 2021 Accepted: 22 Dec 2021

Online: 30 Dec 2021

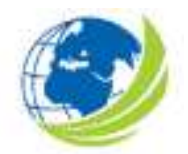

Akurasi: Jurnal Riset Akuntansi dan Keuangan, Vol 3, No.3, 2021, pp. 157 - 166 eISSN 2685-2888

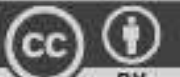

(C) The Author(s) 2021

CC BY This license allows reusers to distribute, remix, adapt, and build upon the material in any medium or format, so long as attribution is given to the creator. The license allows for commercial use. 


\section{PENDAHULUAN}

Ukuran kinerja keuangan sangat penting untuk melihat sejauh mana kemampuan keuangan perusahaan yang diukur dengan menggunakan berbagai ratio keuangan diatanranya rasio profitabilitas dan rasio pertumbuhan. Selain ukuran kinerja keuangan, maka kebijakan keuangan yang digunakan perusahaan juga merupakan faktor internal yang sangat mendukung kinerja keuangan. Kebijakan keuangan perusahaan terdiri dari pengukuran rasio leverage dan rasio likuiditas. Ukuran kinerja keuangan dan ukuran kebijakan keuangan sangat mempengaruhi nilai perusahaan. Likuiditas, manajemen aset, manajemen utang, dan profitabilitas adalah variabelvariabel yang digunakan dalam beberapa penelitian sebelumnya juga dikaitkan dengan ukuran perusahaan. Oleh karena itu, penting untuk perusahaan mengetahui dan mempertimbangkan faktor-faktor yang mempengaruhi nilai perusahaan (Brigham \& Joel, 2010).

Berkembangnya era digital pada saat ini, anak-anak muda milenial sudah mulai berani untuk menginvestasikan dananya pada investasi saham. Ketertarikan para investor untuk berinvestasi tentu dilihat dari perusahaan yang memiliki nilai jual tinggi, maka dari itu nilai perusahaan menjadi unsur utama dalam memberikan kesan yang meyakinkan terhadap para calon investor. Nilai perusahaan adalah kinerja perusahaan yang dicerminkan oleh harga saham yang dibentuk oleh permintaan dan penawaran pasar modal yang merefleksikan penilaian masyarakat terhadap kinerja perusahaan (Harmono, 2016:233).

Untuk memberikan kinerja perusahaan yang baik ini, perusahaan harus membuat berbagai keputusan dengan tepat dan mempertimbangkan dampaknya terhadap harga saham. Keputusan yang dapat mempengaruhi nilai perusahaan dikualifikasikan sebagai keputusan pada bidang manajemen keuangan yang sesuai dengan tanggung jawab seorang manajer keuangan, yaitu mengambil keputusan investasi, mengambil keputusan pendanaan, dan mengambil keputusan dividen. Keputusan tersebut harus diambil secara optimal dalam rangka memaksimalkan nilai perusahaan. Sebagai salah satu contoh kasus, kita dapat melihat pada indeks saham sektor perdagangan dan jasa yang membukukan return 2,81\% dan tercatat bahwa IHSG (Indeks Harga Saham Gabungan) menguat senilai 1,76\% ke level 6.501,38 selama periode Februari 2019, sehingga mencatat kinerja terbaik kedua. Di bawah ini adalah data 10 saham sektor perdagangan dan jasa dengan nilai transaksi terbesar di periode Februari dimana mayoritas saham perusahaan yang memberikan kontribusi return sehingga mencatatkan kinerja terbaik adalah perusahaanperusahaan dengan nilai $\mathrm{PBV} \geq 1 \mathrm{x}$, maka nilai PBV yang overvalued dalam praktiknya akan selalu memberikan imbal hasil atau return yang baik dan positif.

Dalam mengukur nilai perusahaan yang menggunakan metode analisis fundamental price to book value (PBV), penelitian ini juga ingin mengetahui komponen atau faktor internal apa saja yang dapat mempengaruhi nilai perusahaan yang dikualifikasikan sebagai keputusan-keputusan pada bidang manajemen keuangan. Dimana manajer bertanggung jawab untuk mengambil keputusan investasi, keputusan pendanaan, dan keputusan dividen (Mulyanti, 2017). Tujuan penelitian ini yaitu: (1) Mengatahui dan membuktikan adanya pengaruh keputusan investasi terhadap nilai perusahaan. (2) Mengetahui dan membuktikan adanya pengaruh keputusan pendanaan terhadap nilai perusahaan. (3) Mengetahui dan membuktikan adanya pengaruh keputusan dividen terhadap nilai perusahaan. 


\section{KAJIAN PUSTAKA}

\section{Nilai Perusahaan}

Nilai perusahaan merupakan cara pandang atau penilaian investor terhadap tingkat keberhasilan memaksimumkan keuntungan jangka panjang suatu perusahaan yang dapat tercermin dari pergerakan harga pasar sahamnya. Tujuan perusahaan yang paling penting bagi perusahaan adalah memaksimumkan laba, memaksimalkan nilai perusahaan dan meniminumkan biaya (Bararuallo, 2011:44). Menurut Wiyono \& Kusuma (2017:13), memaksimumkan nilai perusahaan bermakna lebih luas dari pada memaksimumkan laba, karena memaksimumkan nilai perusahaan berarti mempertimbangkan berbagai risiko terhadap arus pendapatan perusahaan. Meningkatnya nilai perusahaan adalah sebuah prestasi yang sesuai dengan keinginan para pemiliknya, karena dengan meningkatnya nilai perusahaan maka kesejahteraan para pemilik juga akan meningkat (Setiono, 2015).

\section{Keputusan Investasi}

Saiman, et al (2020) menjelaskan definisi keputusan investasi yang sering juga disebut capital budgeting, yakni keseluruhan proses perencanaan dan pengambilan keputusan mengenai pengeluaran dana yang jangka waktu kembalinya dana tersebut melebihi satu tahun atau berjangka panjang. Penganggaran modal (capital budgeting) memiliki arti penting bagi perusahaan bahwa investasi dalam aset tetap memberikan harapan akan meningkatkan produksi dan penjualan dimasa yang akan datang dan apabila terjadi kesalahan mengambil keputusan investasi mengenai pengeluaran pembelian barang modal akan memiliki akibat yang panjang dan berat (Sitinjak et.al., 2018). Adanya pengaruh keputusan investasi terhadap nilai perusahaan menunjukkan, jika manajer berhasil menciptakan keputusan investasi yang tepat maka aset yang diinvestasikan akan menghasilkan kinerja yang optimal sehingga memberikan suatu sinyal positif kepada investor yang nantinya akan meningkatkan harga saham dan nilai perusahaan. Semakin tinggi investasi yang dilakukan perusahaan, maka akan meningkatkan nilai perusahaan (Tanto et.al., 2019). Menurut Salama, et al (2019), keputusan investasi tidak berpengaruh terhadap nilai perusahaan karena disebabkan oleh faktor ketidakpastian dimasa depan, berupa adanya perubahan teknologi, kondisi sosial ekonomi maupun kebijakan pemerintah.

\section{Keputusan Pendanaan}

Keputusan pendanaan adalah salah satu keputusan keuangan yang mencakup aktivitas pembiayaan investasi maupun operasional perusahaan, hal ini berkaitan dengan upaya pencarian sumber dana yang paling ekonomis atau dengan biaya modal terendah untuk memenuhi jumlah tertentu (Dewi, 2017). Sudana (2015: 175) menjelaskan bahwa menurut Pecking Order Theory, perusahaan lebih menyukai pendanaan internal dari pada pendanaan eksternal. Dana pinjaman dan saham merupakan sumber dana yang berasal dari luar perusahaan, sedangkan laba ditahan merupakan sumber dana yang berasal dari dalam perusahaan. Semakin besar peranan hutang dalam membiayai asetnya dapat memberikan sinyal positif bagi investor, karena peningkatan hutang dianggap sebagai kemampuan perusahaan untuk membayar kewajiban di masa yang akan datang. Penggunaan hutang akan meningkatkan nilai perusahaan, tetapi hanya sampai titik optimum. Setelah titik optimum tersebut, penggunaan hutang dikhawatirkan akan menurunkan nilai perusahaan karena kenaikan keuntungan dari penggunaan hutang tidak sebanding dengan biaya finansial atau kewajiban bunga dari hutang. Dengan demikian keputusan pendanaan dapat menaikan dan menurunkan nilai perusahaan.

\section{Keputusan Dividen}

Keputusan dividen menurut Amaliyah \& Herwiyanti (2020) adalah keputusan yang dikaitkan dengan penentuan apakah laba yang diperoleh perusahaan akan dibagikan kepada para 
pemegang saham sebagai dividen atau akan ditahan dalam bentuk laba ditahan. Apabila semakin besar laba ditahan semakin sedikit jumlah laba yang dialokasikan untuk pembayaran dividen. Keputusan ini akan melibatkan dua pihak yang mempunyai kepentingan yang berbeda, yaitu pihak pertama para pemegang saham, dan pihak kedua perusahaan itu sendiri.

Gordon, 1959; Lintner, 1956 tentang Teori Dividen yang Relevan (The Bird in the Hand) berpendapat bahwa sesungguhnya investor jauh lebih menghargai pendapatan yang diharapkan dari dividen daripada pendapatan yang diharapkan dari keuntungan modal karena investor memandang keuntungan dividen (dividend gain) lebih pasti daripada keuntungan capital gain yang dihasilkan dari laba ditahan. Perusahaan harus menentukan besarnya dividen yang dibagikan, karena penurunan maupun peningkatan jumlah dividen yang dibayarkan seringkali menjadi sinyal bagi pihak investor mengenai prospek pertumbuhan perusahaan di masa yang akan datang (Senata, 2016). Menurut Islami dan Ruzikna (2018) menyatakan bahwa kebijakan dividen tidak ada pengaruh terhadap nilai perusahaan karena meningkatnya nilai dividen tidak selalu diikuti dengan meningkatnya nilai perusahaan sehingga tidak dapat digunakan untuk memprediksi nilai perusahaan.

\section{METODE}

\section{Jenis Penelitian}

Jenis penelitian yang digunakan dalam penelitian ini adalah desain penelitian kausal karena bertujuan untuk melihat hubungan kausal antara variabel bebas dengan variabel terikatnya, yaitu pengaruh variabel independent berupa keputusan investasi, keputusan pendanaan, dan keputusan dividen terhadap variabel dependen nilai perusahaan.

\section{Pengukuran}

Nilai perusahaan dalam penelitian ini menggunakan skala rasio dan diproksikan dengan rasio Price to Book Value (PBV). PBV merupakan rasio harga saham terhadap nilai buku perusahaan yang menunjukkan seberapa besar nilai dari harga per lembar saham dibandingkan dengan nilai dari buku per lembar saham. Harga per lembar saham yang dipakai dalam penelitian ini adalah harga penutupan per akhir bulan April tahun setelahnya dari setiap tahun penelitian.

Keputusan investasi merupakan suatu kebijakan keuangan dalam memakai dana perusahaan yang ada pada sebuah aset yang dimiliki serta diharapkan akan menawarkan keuntungan di masa yang akan datang. Hasil dari keputusan investasi perusahaan dapat dilihat dari total asset growth (TAG) yang merupakan perubahan dari total aset baik kenaikan maupun penurunan yang dihadapi perusahaan dari satu tahun tertentu ke tahun berikutnya.

Keputusan pendanaan adalah suatu kebijakan keuangan yang menyangkut perolehan sumber dana yang akan digunakan untuk kegiatan operasional perusahaan dengan cara diambil dari internal atau akan mengambil dari pihak eksternal. Keputusan pendanaan diproksi dengan Debt Equity Ratio. DER yaitu rasio perbandingan antara total hutang dengan total ekuitas yang bertujuan untuk menganalisa pembelanjaan yang dilakukan perusahaan serta kemampuan perusahaan untuk membayar bunga dan beban lainnya.

Keputusan dividen adalah kebijakan keuangan yang berhubungan dengan berapa banyak jumlah laba yang harus dibayarkan kepada para pemegang saham sebagai dividen dan berapa banyak jumlah yang harus ditahan dalam bentuk laba ditahan sebagai tambahan modal. Variabel keputusan dividen diproksikan dengan Dividend Payout Ratio (DPR) untuk mengukur mengukur berapa besar bagian laba bersih setelah pajak yang dibayarkan sebagai dividen kepada pemegang saham. 


\section{Populasi dan Sampel}

Populasi yang akan menjadi pengamatan dalam penelitian ini adalah seluruh perusahaan sektor perdagangan dan jasa yang terdaftar (listing) di IDX tahun 2015-2019 dengan jumlah terdapat 103 perusahaan. Teknik pengambilan sampel yang digunakan dalam penelitian ini adalah purposive sampling yaitu penentuan sampel dengan pertimbangan atau kriteria tertentu. Berdasarkan pada kriteria pengambilan sampel didapatkan 14 perusahaan, maka jumlah sampel yang digunakan dalam penelitian selama periode 5 tahun adalah 70 sampel.

\section{HASIL DAN PEMBAHASAN}

\section{Analisis Deskriptif}

Tabel 1 menunjukkan bahwa jumlah data $(\mathrm{N})$ pada setiap variabel yaitu 70 data. Nilai terkecil (minimum) untuk nilai perusahaan (PBV) adalah 0,79 dan nilai terbesar (maksimum) adalah 13,71 dengan nilai rata-rata (mean) adalah 3,5823. Nilai terkecil (minimum) untuk keputusan investasi (TAG) adalah -14,05 dan nilai terbesar (makimum) adalah 123,67 dengan nilai rata-rata (mean) adalah 14,1055. Nilai terkecil (minimum) untuk keputusan pendanaan (DER) adalah 0,13 dan nilai terbesar (maksimum) adalah 4,29 dengan nilai rata-rata (mean) adalah 1,0603. Nilai terkecil (minimum) untuk keputusan dividen (DPR) adalah 2,42 dan nilai terbesar (maksimum) adalah 92,30 dengan nilai rata-rata (mean) adalah 41,6149.

\section{Tabel 1.}

Hasil Analisis Statistik Deskriptif

\begin{tabular}{ccccc}
\hline & $\mathrm{N}$ & Minimum & Maximum & Mean \\
\hline PBV & 70 &, 79 & 13,71 & 3,5823 \\
TAG & 70 & $-14,05$ & 123,67 & 14,1055 \\
DER & 70 &, 13 & 4,29 & 1,0603 \\
DPR & 70 & 2,42 & 92,30 & 41,6149 \\
\hline
\end{tabular}

Sumber: Output SPSS Versi 25 (2021)

\section{Uji Kecocokan Model}

Nilai koefisien korelasi (R) adalah 0.361 terletak pada interval koefisien 0 s.d. 0,49 yang berarti tingkat hubungan antara keputusan investasi (TAG), keputusan pendanaan (DER), dan keputusan dividen (DPR) memiliki hubungan yang lemah terhadap nilai perusahaan. Nlai koefisien determinasi $\mathrm{R}$ Square adalah 0,130 atau sekitar 13\%. Dapat disimpulkan angka tersebut menunjukkan bahwa keputusan investasi (TAG), keputusan pendanaan (DER), dan keputusan dividen (DPR) memiliki kontribusi dalam menerangkan variasi variabel nilai perusahaan sebesar $13 \%$ sedangkan sisanya sebesar $87 \%(100 \%-13 \%=87 \%)$ dipengaruhi oleh variabel lain, yang berarti kemampuan variabel-variabel keputusan investasi (TAG), keputusan pendanaan (DER), dan keputusan dividen (DPR) dalam menjelaskan variasi variabel nilai perusahaan (PBV) sangat terbatas.

Berdasarkan tabel 2 hasil uji $\mathrm{F}$ anova dapat diketahui bahwa nilai signifikansi 0.026 lebih kecil dari 0,05 $(0,000<0,05)$. Dengan demikian dapat disimpulkan bahwa masing-masing variabel 
keputusan investasi (TAG), keputusan pendanaan (DER), dan keputusan dividen (DPR) secara simultan dan signifikan berpengaruh terhadap nilai perusahaan (PBV).

Tabel 2.

Hasil Regresi

\begin{tabular}{lrrrr}
\hline Variabel & Koefisien & SE & t-value & Sig \\
\hline TAG &, 007 &, 017 &, 436 &, 664 \\
DER &,- 190 &, 289 &,- 657 &, 514 \\
DPR &, 043 &, 016 & 2,761 &, 007 \\
R Square & .130 & & & \\
F-Statistics (sig) & .026 & & & \\
\hline
\end{tabular}

\section{Pengaruh Keputusan Investasi (TAG) Terhadap Nilai Perusahaan (PBV)}

Hasil penelitian ini menunjukkan tidak ada pengaruh signifikan dari keputusan investasi terhadap nilai perusahaan yang menunjukkan bahwa pertumbuhan aset bukan menjadi faktor utama untuk meningkatkan nilai perusahaan. Hasil penelitian ini tidak sejalan dengan teori sinyal yang menyatakan bahwa keputusan pengeluaran untuk investasi akan menginformasikan sinyal positif tentang pertumbuhan perusahaan dimasa akan datang yang ditandai oleh meningkatnya harga saham sebagai indikator nilai perusahaan, namun akan memberikan sinyal buruk (bad news) jika nilai TAG terus meningkat maka akan menggambarkan perusahaan yang tidak mampu mengelola dan memanfaatkan aset dengan baik di mana pengelolaan aset yang buruk menyebabkan laba yang diperoleh perusahaan tidak optimal. Sinyal negatif ini akan membuat harga saham menjadi turun sehingga nilai Price to Book Value akan rendah. Hasil penelitian ini mendukung hasil penelitian yang dilakukan oleh Gautama, Oktavia, dan Nurhayati (2019), serta Hidayat (2018).

\section{Pengaruh Keputusan Pendanaan (DER) Terhadap Nilai Perusahaan (PBV)}

Hasil penelitian ini menunjukkan bahwa keputusan pendanaan tidak mempunyai pengaruh signifikan terhadap nilai perusahaan. Hal ini terjadi karena investor tidak terlalu memperhitungkan proporsi hutang yang dimiliki perusahaan baik secara internal atau pun eksternal sebagai tolak ukur investor untuk menyetor dananya ke perusahaan tersebut, karena kebijakan atau keputusan dalam penentuan proposi hutang dalam perusahaan akan menjadi wewenang pihak manajemen perusahaan itu sendiri dan yang diperhatikan investor hanyalah tingkat return yang diharapkan dari hasil penanaman modal kepada perusahaan tersebut. Keputusan pendanaan yang semakin meningkat akan mengindikasikan beban yang ditanggung semakin besar dan potensi dari kebangkrutan pun akan besar pula, karena penggunaan utang yang masih belum optimal membuat investor tidak melihat peluang investasi melalui keputusan pendanaan. Hasil penelitian ini juga tidak selaras dengan Pecking Order Theory yang menyatakan bahwa perusahaan lebih menyukai pendanaan internal dari pada pendanaan eksternal karena pada nyatanya meningkatnya rasio DER menandakan bahwa rata-rata perusahaan sektor perdagangan dan jasa masih mengutamakan pemakaian dana eksternal sebagai sumber pendanaan perusahaan. Hasil penelitian ini konsiten dengan penelitian yang dilakukan oleh Jesilia dan Purwaningsih (2020), Piristina dan Khairunnisa (2019), serta Amaliyah dan Herwiyanti (2020).

\section{Pengaruh Keputusan Dividen (DPR) Terhadap Nilai Perusahaan (PBV)}

Hasil penelitian ini membuktikan bahwa kebijakan deviden memiliki pengaruh positif dan signifikan terhadap nilai perusahaan. Hasil penelitian ini sejalan dengan Bird in The Hand Theory yang menyatakan bahwa investor merasa lebih aman memperoleh pendapat berupa pembayaran dividen yang lebih pasti karena meminimalisir resiko yang diterima dibandingkan dengan 
mengharapkan capital gain. Para investor juga akan melihat kenaikan dividen sebagai sinyal positif atas prospek perusahaan di masa depan dan perusahaan akan mendapatkan nilai kepercayaan yang tinggi dari para investor. Sehingga semakin tinggi dividen yang dibagikan akan meningkatkan permintaan saham yang diikuti oleh meningkatnya nilai perusahaan. Hasil penelitian ini selaras dengan hasil penelitian yang dilakukan oleh Sihwahjoeni dan Bili (2020), Triani dan Tarmidi (2019), serta Salama, Rate, dan Untu (2019).

\section{KESIMPULAN}

Berdasarkan hasil penelitian yang telah dilakukan secara deskriptif maupun statistik, maka diperoleh kesimpulan sebagai berikut: (1) keputusan investasi tidak berpengaruh signifikan terhadap nilai perusahaan yang memiliki arti bahwa tidak berpengaruhnya keputusan investasi disebabkan adanya faktor ketidakpastian dimasa depan, berupa adanya perubahan teknologi, serta kondisi sosial ekonomi. (2) Keputusan pendanaan tidak berpengaruh signifikan terhadap nilai perusahaan, hal ini dikarenakan penggunaan utang yang masih belum optimal dan telah mencapai titik maksimum membuat investor tidak melihat nilai perusahaan melalui keputusan pendanaan. (3) Keputusan dividen berpengaruh positif signifikan terhadap nilai perusahaan, karena meningkatnya nilai dividen yang dibagikan akan meningkatkan permintaan saham yang diikuti oleh meningkatnya nilai perusahaan.

\section{Implikasi}

Diharapkan hasil penelitian ini dapat menjadi bahan perbandingan dan referensi sehingga dapat melanjutkan penelitian yang berkaitan dengan nilai perusahaan menggunakan faktor-faktor eksternal seperti inflasi, suku bunga. Serta menambahkan sampel penelitian yang bukan hanya pada sektor perdagangan dan jasa sehingga sampel yang diteliti lebih banyak.

\section{REFERENSI}

Amaliyah, Fitri dan Eliada Herwiyanti. (2020). Pengaruh Keputusan Investasi, Ukuran Perusahaan, Keputusan Pendanaan, Dan Kebijakan Dividen Terhadap Nilai Perusahaan Sektor Pertambangan. Jurnal Penelitian Ekonomi dan Bisnis, 5 (1), 39 - 51. DOI: 10.33633/jpeb.v5i1.2783 Diakses tanggal 06 November 2020.

Bursa Efek Indonesia. Tersedia pada: http://www.idx.co.id (diakses pada Januari 2021).

David Wijaya. 2016. Praktikum Manajemen Keuangan 1 Berbasis IFRS. Edisi Pertama. Jakarta: Mitra Wacana Media.

Dewi, Putu Sri Mae Yanti dan Dewa Gede Wirama. (2017). Pecking Order Theory Pengaruh Profitabilitas Dan Pertumbuhan Perusahaan Pada Keputusan Pendanaan Perusahaan. EJurnal Akuntansi Universitas Udayana. Vol.18.3. Maret 2017. 2423-2450. ISSN: 2302-8556.

Elizabeth Lucky Maretha Sitinjak, Kristiana Haryanti, Widuri Kurniasari, Wisnu Djati. (2018). Manajemen Keuangan Terapan: Keputusan Investasi \& Personaliti Disc. Semarang: Penerbit Universitas Katolik Soegijapranata. ISBN : 978-602-6865-71-7.

Frans Bararualllo. 2011. Nilai Perusahaan Konsep, Teori dan Aplikasi. Jakarta: Penerbit Universitas Atmajaya. ISBN 978-602-8904-13-1

Gautama, B. P., Octavia, N. K., \& Nurhayati, N. S. (2019). Pengaruh Keputusan Investasi dan Keputusan Pendanaan terhadap Nilai Perusahaan pada Sektor Properti, Real Estate, dan Konstruksi Bangunan yang Terdaftar di Bursa Efek Indonesia Periode 2013-2017. 
Organum: Jurnal Saintifik Manajemen dan Akuntansi, 2(2), 117-129. https://doi.org/10.35138/organum.v2i2.49 Diakses tanggal 07 September 2021.

Gendro Wiyono dan Hadri Kusuma. 2017. Manajemen Keuangan Lanjutan Berbasis Corporate Value Creation. Edisi kesatu. Yogyakarta: UPP STIM YKPN.

Gordon, M.J. (1959). Dividends, Earnings, and Stock Prices. The Review of Economics and Statistics. Vol. 41, No. 2, Part 1: 99-105. http://www.jstor.org/stable/1927792 Diakses tanggal 06 November 2020.

Harmono. 2016. Manajemen Keuangan: Berbasis Balanced Scorecard Pendekatan Teori, Kasus, dan Riset Bisnis. Jakarta: Bumi Aksara.

Hidayat, Khomarul. 25 Februari 2019. Ini 10 saham sektor perdagangan dengan nilai transaksi terbesar (18-22 Februari 2019). Berita Investasi Kontan.Co.Id. Diakses pada 22 Maret 2021 dari World Wide Web: https://investasi.kontan.co.id/news/ini-10-saham-sektorperdagangan-dengan-nilai-transaksi-terbesar-18-22-februari-2019 \

Hidayat, Muwafick. (2018). Faktor Yang Mempengaruhi Price to Book Value. Jurnal Bisnis Dan Akuntansi. Vol. 20, No. 2, 101-106. ISSN: 1410-9875.

I Made Sudana. 2015. Manajemen Keuangan Perusahaan Teori Dan Praktik. Edisi Kedua. Jakarta: Erlangga.

Islami, Hafizh dan Ruzikna. (2018). Pengaruh Keputusan Investasi, Keputusan Pendanaan Dan Kebijakan Dividen Terhadap Nilai Perusahaan Pada Perusahaan Sektor Pertambangan Yang Terdaftar Di Bursa Efek Indonesia Periode 2011-2015. JOM FISIP. Vol. 5: Edisi II, Hal: 1-13.

Jesilia, J., \& Purwaningsih, S. (2020). Pengaruh Keputusan Investasi, Keputusan Pendanaan dan Kebijakan Dividen Terhadap Nilai Perusahaan. Profita : Komunikasi Ilmiah Akuntansi dan Perpajakan, 13(1), 157-164.

Lintner, John. (1956). Distribution of Incomes of Corporations among Dividends, Retained Earnings, and Taxes. The American Economic Review. Vol. 46, No. 2: 97-113. http://www.jstor.org/stable/1910664 Diakses tanggal 06 November 2020.

Mulyanti, Dety. (2017). Manajemen Keuangan Perusahaan. Akurat Jurnal Ilmiah Akuntansi, 8(2), 62-71. ISSN 2086-4159.

Piristina, Feny Alvita dan Khairunnisa. (2019). Analisis Pengaruh Kebijakan Dividen, Keputusan Investasi, Dan Keputusan Pendanaan Terhadap Nilai Perusahaan. Jurnal Aset (Akuntansi Riset) Program Studi Akuntansi FPEB UPI, Vol. 11 No. 1: 123-136. ISSN: 2541-0342. https://doi.org/10.17509/jaset.v11i1.16620 Diakses tanggal 06 November 2020.

Saiman, Hermiliana Petra, M. Idris, dan Thanwain. (2020). Pengaruh Keputusan Investasi, Keputusan Pendanaan Terhadap Nilai Perusahaan Pada Bursa Efek Indonesia. Economics Bosowa Journal Edisi XXXIII, 6(1), 50-60.

Salama, Merina, Paulina Van Rate, dan Victoria N. Untu. (2019). Pengaruh Keputusan Investasi, Keputusan Pendanaan Dan Kebijakan Dividen Terhadap Nilai Perusahaan Pada Industri Perbankan Yang Terdaftar Di Bei Periode 2014-2017. Jurnal EMBA. Vol.7 No.3: 2651 - 2660. ISSN 2303-1174.

Senata, Maggee. (2016). Pengaruh Kebijakan Dividen Terhadap Nilai Perusahaan Yang Tercatat Pada Indeks LQ-45 Bursa Efek Indonesia. Jurnal Wira Ekonomi Mikroskil, Volume 6, Nomor 01, 73-84.

Setiono, Benny Agus. (2015). Teori Perusahaan / Theory Of The Firm : Kajian Tentang Teori Bagi Hasil Perusahaan (Profit And Loss Sharing) Dalam Perspektif Ekonomi Syariah. Jurnal Aplikasi Pelayaran dan Kepelabuhanan, Volume 5, Nomor 2, Maret 2015 : 153-169. 
ISSN:2654-4911. http://dx.doi.org/10.30649/jurapk.v5i2.40 Diakses tanggal 05 November 2020.

Sihwahjoeni, Subiyantoro, Edi and Bili, Maria Ringi. (2020). Analysis Effect of Investment Decision, Financing and Dividend Policy on Value Company with Variable Business Risk as Mediation. International Journal of Research and Scientific Innovation (IJRSI), 7 (7). pp. 261-269. ISSN 2321-2705

Spence, Michael. (1973). Job Market Signaling. The Quarterly Journal of Economics, Vol. 87, No. 3. (Aug., 1973), pp. 355-374.

Sukmawati Sukamulja. 2018. Pengantar Pemodelan Keuangan dan Analisis Pasar Modal. Yogyakarta: ANDI.

Tanto, Tania Ivanna A., Aaron M. A. Simanjuntak, dan Bill J. C. Pangayow. (2019). Pengaruh Kesan Investasi, Keputusan Pendanaan Dan Kebijakan Deviden Terhadap Nilai Perusahaan. Jurnal Akuntansi \& Keuangan Daerah, Volume 14, Nomor 1, 162-177.

Triani, N., Tarmidi, D. (2019). Firm Value: Impact of Investment Decisions, Funding Decisions and Dividend Policies. International Journal of Academic Research in Accounting, Finance and Management Sciences, 9 (2): 158-163. http://dx.doi.org/10.6007/IJARAFMS/v9-i2/6107 Diakses tanggal 4 September 2021.

Werner R. Murhadi. 2013. Analisis Laporan Keuangan, Proyeksi dan Valuasi Saham. Jakarta: Salemba Empat. 


\section{DECLARATIONS}

\section{Funding}

The authors received no financial support for the research and publication of this article.

\section{Conflicts of interest/ Competing interests:}

The authors have no conflicts of interest to declare that are relevant to the content of this article.

\section{Data, Materials and/or Code Availability:}

Data sharing is not applicable to this article as no new data were created or analyzed in this study.

\section{How to cite this Article}

Bucharni, B., \& Hariani, S. (2022). Pengaruh Komponen Keputusan Keuangan Terhadap Nilai Perusahaan. AKURASI: Jurnal Riset Akuntansi Dan Keuangan, 3(3), 157 - 166 